\title{
Examining the Effects of Environmental Policy on Shale Gas Production: The Case of Alberta, Canada
}

\author{
Peter Langer, Dale Carl, Philip R. Walsh* \\ Ted Rogers School of Management, Ryerson University, Toronto, Canada \\ Email: *prwalsh@ryerson.ca
}

How to cite this paper: Langer, P., Carl, D. and Walsh, P.R. (2017) Examining the Effects of Environmental Policy on Shale Gas Production: The Case of Alberta, Canada. Journal of Geoscience and Environment Protection, 5, 93-108.

https://doi.org/10.4236/gep.2017.59007

Received: July 21, 2017

Accepted: September 3, 2017

Published: September 6, 2017

Copyright (@) 2017 by authors and Scientific Research Publishing Inc. This work is licensed under the Creative Commons Attribution International License (CC BY 4.0).

http://creativecommons.org/licenses/by/4.0/

\begin{abstract}
The increase in natural gas production in North America resulting from the implementation of new technologies related to the fracturing (fracking) of natural gas-bearing shale reservoirs has enhanced the security of supply and lowered energy costs in the continent. Yet the environmental impact associated with shale gas development has raised concerns and debate among energy and environmental policy makers as to how best to address these concerns. As Canada's largest producer of natural gas, the Province of Alberta is an example of a jurisdiction with numerous regulations for dealing with such environmental risks. This paper applies the CO/RE model of Konschnik and Bolingin examining Alberta's environmental regulatory framework and the impact; it will have on further shale gas production in the province. Aside from the identification of risks associated with increased seismicity, the results of this examination suggest that the current regulatory environment does not appear to have any adverse effect on current and future shale gas production within the province. Furthermore, Alberta's environmental regulation has influenced shale gas producers to pursue innovation in technology and engineering practice and has helped establish a collaborative approach to mitigating environmental risk.
\end{abstract}

\section{Keywords}

Shale Gas, Environmental Regulation, Fracking, Alberta

\section{Introduction}

The recent popularity of shale gas production has led to a new era termed the "golden age of gas", which has been made possible by a process known as frack- 
ing [1]. This new phenomena has caught the attention of many climate change policymakers. This attention is heightened due to the fact that there is currently international action being taken to better understand the causes of climate change and to create policies that would reduce greenhouse gas emissions by encouraging a move from investment in traditional fossil fuels as primary energy sources to zero-carbon energy sources such as solar, wind and nuclear power [2]. The main way governments are trying to address this issue is through policy and regulation [3] [4] and it is becoming more evident that this is occurring using a "bottom to top" approach where policy development occurs at regional and local levels [5]. Academics have analyzed the effectiveness of various environmental policies, such as the Kyoto Accord [6], and why these policies are sometimes ineffective [7]. Frameworks have been suggested by researchers for criteria that will help to implement effective and meaningful policies, such as the CO/RE (Characterization, Optimization, Regulation, Enforcement) framework [8]. Additionally, models have been proposed that attempt to incorporate the effects of policy on natural gas production in the USA [9].

Apart from the existing industrial sector regulations on emissions, it is not clear yet which restrictive protective policies will be implemented in Canada and more specifically Alberta, or to what degree they will affect shale gas production. One of the main reasons for this uncertainty is the various environmental debates which have been articulated in the work done by the Yale School of Forestry and Environmental Studies. This group has addressed three main topics which are currently being debated with respect to the fracking process: the effects on air quality, the implications for water tables, and its relation to earthquakes [10]. Decisive conclusions have not been drawn on the long-term effects of any of these questions, which can make it difficult for governments to implement effective policies related specifically to the process of shale gas extraction. Furthermore, since natural gas is considered one of the transition fuels for a low-carbon economy [11], the support for shale gas production has also been positioned, in some circles, as an environmentally friendly alternative to the traditional carbon-emitting fuel sources such as coal and petroleum.

Lastly, in a country that has an abundant supply of this resource, Canada has to be careful in the regulation that it elects to enact as it can have large economic and environmental impacts [12]. There has already been significant investment from industry into infrastructure to extract this resource [11]. Therefore, the government can expect substantial resistance from industry to any regulation that will restrict access to this resource. To add to this, the Canadian government has a history of not enforcing strong regulation on this industry [6] [7].

In this paper, the regulations governing shale gas extraction activities will be analyzed. Knowledge will be built around the effectiveness of these policies when they are put into practice and using the CO/RE model, a conclusion will be drawn with regards to the impact of environmental policy and regulation on Alberta shale gas production in the current political and regulatory environment. 


\section{Current Regulation in Canada}

When it comes to the regulation of natural resources in Canada, both the federal and provincial governments have important roles to play. The regulation of the development of land is done mostly the same across Canada, with the exception of Quebec (Quebec has a first-come first-serve system). There are two ways in which exploration and production rights are acquired-one where the provincial legislation has dictated that mineral rights belong to the Crown and one where mineral rights are owned by the land owner. In the former case it is usually through land sales run by the province where bids are awarded and in the latter case it is through direct negotiation with the landowner. In both cases, the surface rights remain with either the Crown or the landowner with access rights determined in both cases through negotiation [13].

The federal government's role is to manage interprovincial energy trade, cross-jurisdiction pipelines, pollution prevention, habitat protection, regulatory oversight of chemicals in addition to resource regulation in the Canadian North, offshore marine areas and Aboriginal lands [13]. This management is done in part by four groups: Natural Resources Canada, Environment Canada, Health Canada and the National Energy Board [13]. When it comes to the provinces, as stated under the Canadian Constitution, "provinces own onshore resources within their borders and are the primary relator of their development" [13].

There are three main areas in which regulators are concerned: effects on water resources, on air and on land. With regard to the regulation of water, provinces are responsible for authorizing water withdrawals [14]. Provincial jurisdiction also applies to waste water and the hazardous chemicals that are generated from the fracking process. However, Environment Canada and Health Canada have an obligation to assess new chemical substances that are made in, or imported to Canada, including those that are used in the fracking process [14]. Air quality is also largely regulated at the provincial level as opposed to the federal level. By way of example,

“...the Alberta Energy Regulator (AER) states, 'For concerns such as increased truck traffic, the AER will work with counties and municipalities by providing information about potential developments to support their preparation for increasing activity.' Other jurisdictions, including New Brunswick, are planning to monitor air quality specifically related to shale gas operations.” ([14], p. 12).

Lastly, land use is also regulated at the provincial level. These regulators decide on specific projects by using two main criteria, the cumulative impacts of all projects on the region and how the specific project's development fits with the region's land-use plans [14].

\subsection{The Scope of Shale Gas in Canada}

Understanding the scope of the Canadian shale gas capacity is critical when identifying what exactly will be impacted with any potential regulation or policy. In their review of regional and global resource estimates, McGlade, Speirs and 
Sorrell conclude that Canada could have as much as 3.6 to 28.2 trillion cubic meters $(\mathrm{Tcm})$ of shale gas within its borders [12]. Also in this study, McGlade, et al., indicate that the best estimate of the technically recoverable shale gas would be $12.0 \mathrm{Tcm}$, an amount equal to 122 years of natural gas supply for Canada using total annual natural gas consumption in 2015 of 98 billion cubic meters $(\mathrm{Bcm})$ [15]. Technically recoverable gas is defined as the amount of shale gas which is economically recoverable given current technology and extraction methods as well as gas that is considered to be in undiscovered formations.

Taking a deeper look into Canadian shale gas production, Rivard et al. found that there were 14,000 (of Canada's 500,000 total oil and gas wells) used for fracking, as of 2013 [11]. However, that 14,000 figure also includes wells drilled for all unconventional oil and gas plays (including shale liquids, tight oil and gas and coal bed methane). In this report, they summarize how many of the processes involved in the fracturing process-mainly around the liquid solution which is pumped into the ground-are not yet regulated. While companies operating within the industry are attempting to utilize processes that are environmentally friendly, many institutions, specifically governments and universities, are working to provide a scientific base for the impending regulations.

In addition to the current reserve estimates, the International Energy Agency (IEA) has projected Canada's natural gas capabilities stretching out to 2035. Also included in these estimates is the amount of gas which could come from unconventional gas plays. See Figure 1 below. From this infographic, it can be seen that the IEA estimates unconventional gas to make up just less than 175 billion cubic meters annually, which would equate to nearly $70 \%$ of all natural gas production in Canada.

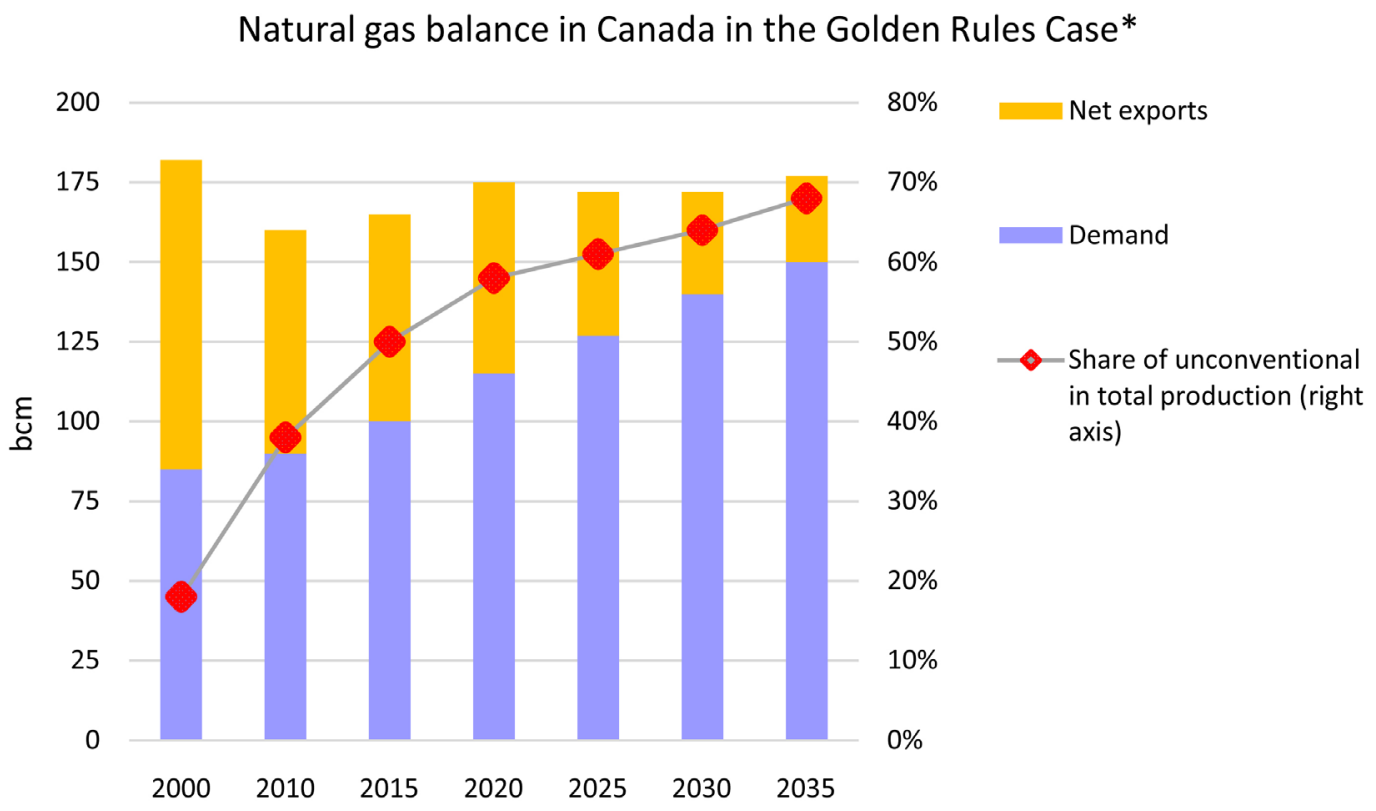

Figure 1. Canadian natural gas production capability. Source: International Energy Agency. ${ }^{\star}$ The sum of demand and net exports represents total production. 


\subsection{Scope of Shale Gas in Alberta}

Much of Canada's shale gas is located within the provincial borders of Alberta. In a recent geological survey of the shale gas formations located in Alberta, the Alberta Geological Survey (AGS) has determined there to be 15 to be identified as distinct formations [16]. In the same report this survey analyzed five formations, the:

- Duvernay

- Muskwa

- Basal Banff/Exshaw

- North Nordegg

- Wilrich

Collectively these formations could contain as much as $1291 \mathrm{Tcf}$ of gas-in-place [16]. In total, the Alberta Energy Regulator (AER) has estimated that the total shale gas in place within the province is 3424 trillion cubic feet [17]. From that amount, in 20130.02 billion cubic feet per day was being produced, which equates to just over 7 billion cubic feet of production annually. Furthermore, hydraulic fracturing has been incorporated into more than 10,000 wells from the 2008 to 2015 time frame. These 10,000 wells utilize a combination of multi-stage fracking and horizontal drilling techniques [18].

\section{Environmental Policy Analysis}

As discussed in the introduction section, the goal of this paper is to determine the impact that environmental policy implemented in Canada and specifically, Alberta will have on the available shale gas production over the course of the current government's term in office. Given that the Canadian parliamentary system does not have a fixed term, the time scale will be determined by the Constitutional requirement to hold an election within five years. Therefore, the effects of these policies will be measured until the year 2020. In this section two topics will be discussed, the current proposed policies by the federal government as well as Alberta, a key provincial government. The second topic will describe the model which will be used to determine the impact of these policies on available shale gas production.

\subsection{Environmental Regulations-Federal Government}

Due to the nature of natural resource regulation, as outlined in the current regulation section of this paper, the federal government has a limited ability to effect the treatment of these resources in each province. The federal government's role in implementing environmental policy must therefore be assessed at a high level. This type of role then becomes more of a reporting and analysis agency that tends to mainly monitor the developments and trends related to energy extraction. Where they do hold authority is in the maintenance of inter-provincial and international energy trade and infrastructure [11]. Furthermore, the federal government is concerned with implementing policies that will allow for eco- 
nomic development to continue and grow within its national borders. One initiative that the federal government has been managing is the Federal Sustainable Development Strategy. In its current state the federal government is focused on five main goals [19]:

- Taking Action on Climate Change.

- Clean Technology, Jobs and Innovation.

- National Parks, Protected Areas and Ecosystems.

- Freshwater and Oceans.

- Human Health, Well-being and Quality of Life.

The new federal government is attempting to make this an interactive and democratic exercise by requesting citizen participation [19]. However, this initiative will tend to lead to the types of indicators and measurements that this body will be monitoring as opposed to specific regulations that will limit or expand the availability of shale gas production in Alberta. Such regulation is taken care of at the provincial and industry level and the federal government will have very little direct impact on the natural gas production that comes from shale plays. In the next section of this paper we discuss the regulatory environment that exists in Alberta and how this could impact shale gas that is produced within the province.

\subsection{Environmental Regulation-Alberta Government}

The regulatory environment that manages energy regulation in Alberta has evolved quite a bit over the decades. It went from a much more fragmented type of governance, in which different governing bodies managed the beginning phases of a resource extraction project to different bodies that regulate different aspects of resources and the environment (Table 1).

Table 1. Alberta regulatory agencies.

\begin{tabular}{|c|c|}
\hline Governance Body & Regulatory Responsibility \\
\hline Alberta Department of Energy & $\begin{array}{l}\text { administration of the provincial legislation } \\
\text { governing the ownership of oil and gas }\end{array}$ \\
\hline Alberta Energy Regulator & $\begin{array}{l}\text { oversight of energy development from application } \\
\text { and exploration, to construction and development, } \\
\text { to abandonment, reclamation, and remediation }\end{array}$ \\
\hline $\begin{array}{l}\text { Alberta Environment and Parks } \\
\text { (Formerly Environment and } \\
\text { Sustainable Resource Development) }\end{array}$ & $\begin{array}{l}\text { protecting and managing the environment, water } \\
\text { resources, climate change and waste management }\end{array}$ \\
\hline Alberta Surface Rights Board & $\begin{array}{l}\text { managing conflicts over surface rights and does } \\
\text { this by being an independent tribunal } \\
\text { established by the province }\end{array}$ \\
\hline Alberta Utilities Commission & $\begin{array}{l}\text { managing breaches, objections and complaints } \\
\text { arising under certain utility specific regulation, } \\
\text { including routes, tolls and tariffs approvals for } \\
\text { construction of pipelines and distribution facilities }\end{array}$ \\
\hline
\end{tabular}


In 2013 the province of Alberta decided to centralize much more of this control by turning over almost all of the regulatory affairs related to energy resource extraction to the AER. This centralization has certainly helped to make this regulatory environment much easier to navigate as there is one main touch point acting as the catch-all regulator. The regulator has identified a variety of policy enhancements in the following areas of environmental sensitivity that might be impacted by shale gas production [18]:

- Water management.

- Groundwater protection.

- Wellbore integrity.

- Air quality.

- Noise and light.

- Induced seismicity.

A summary of the existing policies and regulations pertaining to each of these areas is contained within Table 2. Induced seismicity refers to the seismic events (earthquakes) that may be triggered by the operations that are being carried out by the industry. Currently, there are no specific regulations pertaining to this factor. However, the AER is in charge of monitoring these events through the Regional Alberta Observatory for Earthquakes Studies Network.

Table 2. Policies and regulations pertaining to areas of environmental sensitivities related to shale gas production.

\begin{tabular}{|c|c|}
\hline Area & Policies and regulations \\
\hline Water management & 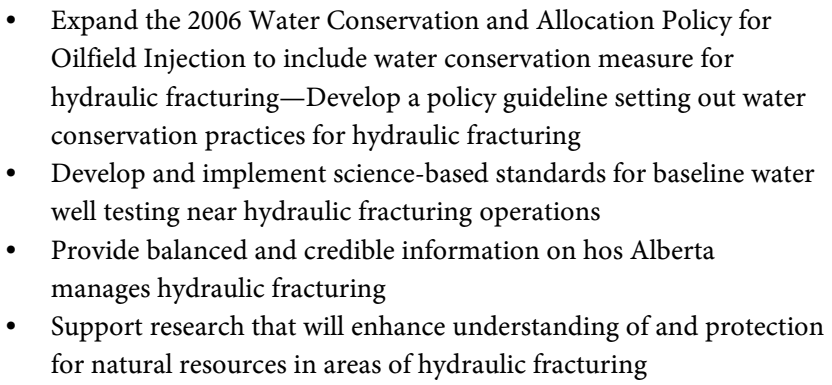 \\
\hline $\begin{array}{l}\text { Groundwater } \\
\text { protection }\end{array}$ & $\begin{array}{l}\text { - Directive 083: Hydraulic Fracturing-Subsurface Integrity } \\
\text { - Directive 059: Well Drilling and Completion Data Filing } \\
\text { Requirements } \\
\text { - Directive 055: Storage Requirements for the Upstream Petroleum } \\
\text { Industry } \\
\text { - Directive 058: Oilfield Waste Management Requirements of the } \\
\text { Upstream Petroleum Industry }\end{array}$ \\
\hline Wellbore integrity & $\begin{array}{l}\text { - Directive 008: Surface Casing Depth Requirements } \\
\text { - Directive 009: Casing Cementing Minimum Requirements } \\
\text { - Directive 083: Hydraulic Fracturing-Subsurface Integrity }\end{array}$ \\
\hline Air quality & - Alberta Ambient Air Quality Objectives and Guidelines \\
\hline Noise and light & $\begin{array}{l}\text { - Directive 056: Energy Development Applications and Schedules } \\
\text { - Directive 038: Noise Control }\end{array}$ \\
\hline Induced seismicity & - No specific regulations pertaining to this area \\
\hline
\end{tabular}




\section{The Model-CO/RE}

As laid out in the previous section, the regulations impacting shale gas production in Alberta is complex, especially because there are not specific "catch-all" regulations that specifically preclude the extraction of shale gas on a broad basis. Given this complexity a model has been suggested by Konschnikand Boling with the acronym CO/RE that addresses the Characterization of Risk, Optimization of mitigation strategies, Regulation and Enforcement [8]. A visual representation of this model can be seen in Figure 2.

This model or framework lends itself to the complexity of regulation regarding shale gas and therefore will be applicable for the assessment of shale gas production in Alberta. This model has also been cited in a variety of recent scholarly policy assessments pertaining to shale gas production [20] [21] [22] [23].

This model works in a sequential fashion. The Characterization of Risk is the first step in the framework as it is an assessment of the risks of carrying out the activity of shale gas production and the identification of potential hazards to the social and ecological environments for which specific measures can be determined and related regulatory agencies informed. The second step involves the Optimization of Mitigation Strategies where an effort can be made to address the industry's ability to mitigate adverse risks either through industry collaboration or the use of incentives such as government support for innovation. Regulation is the center piece of this model within the context of this paper as it focusses on the regulator's ability to either make the shale gas accessible or deem that it is not in the interest of the public to institute regulations that would allow for its extraction. Finally, Enforcement supports the effectiveness of the regulation after said regulations have been instituted. The process of enforcement helps confirm the impact of risks that can be encountered in shale gas production and informs the first step of the framework.

\section{Application of the CO/RE Model}

In order to apply the CO/RE model to the shale gas industry in Alberta, a brief discussion entails addressing each of the six core environmental issues that

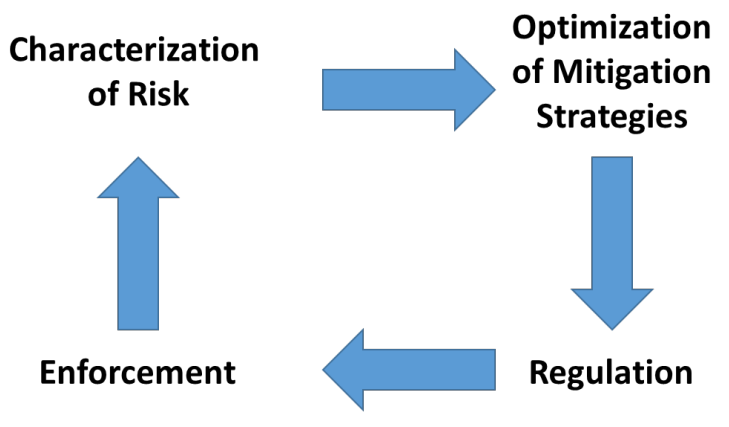

Figure 2. CO/RE model. (After Konschnik and Boling 2014). 
regulators are currently assessing within Alberta and identifies how each step of the framework would inform stakeholders, concluding with observations as to whether the risks, mitigation strategies, regulation and enforcement positively or negatively impact the Alberta shale gas industry.

\subsection{Water Management and Groundwater Protection}

The Alberta government, through the Alberta Environment and Parks (AEP) is able to regulate the quality of the water in relation to upstream oil and gas operations [18]. In 2014 the AEP (Formerly Environment and Sustainable Resource Development (ESRD)) published The Water Conservation Action Plan, titled "Our Water, Our Future: A Plan for Action" [24]. In this plan short-term actions were laid out with respect to hydraulic fracturing (see Table 2). The Alberta government through the AER has also released four directives that the industry must abide in order to remain in compliance (see Table 2).

Characterization of Risk: The findings in a study produced by the United States Environmental Protection Agency (EPA) suggested that there are some risks to above ground and sub-surface water aquifers [25]. The largest risk for water management occurred in areas in which water availability was considered low. The largest risk for the groundwater protection came when spills of fracking fluid occurred or if there was inadequate treatment of the water used in the process before it was returned to the aquifer [25].

Optimization of mitigation strategies. Issues related to water resources are clear pain-points for the fracking industry and therefore there is considerable action taken to mitigate the risks mentioned above. For this particular reason the ESRD (now the AEP) surveyed the Alberta population to better understand how to take on issues related to water as it pertains to fracking and has begun to take a more proactive approach to mitigating these risks across all water resources throughout Alberta [26]. Furthermore, industry players have introduced innovation measures to mitigate impacts on groundwater and surface water in recent years [27] [28].

Regulation: In addition to the proactive approach that the AER is taking, the four directives referred to earlier have been implemented to help ensure that the current water extraction and replacement are within the interest of the public. Under Directive 083, the industry must submit to the AER a hydraulic notification form. The intention of this process is to prevent the loss of well integrity, reduce the likelihood of unintentional inter-wellbore communication between the subject well and an offset well and in such an event manage well control at the offset well, prevent adverse effects to non-saline aquifers and water wells, and prevent surface impacts [29]. The purpose of Directive 059 is to ensure that the industry is submitting, timely and complete information regarding their activities related to well drilling and well abandonment. Additionally, under this directive the industry is required to report the fracturing fluid that they use and the water source data and submit this information on a daily basis [30]. Directive 055 has six main components that help to regulate the storage that is in- 
volved when producing hydro-carbons; primary containment devices, secondary containment systems, leak detection systems, spill prevention and loss control systems, weather protection, and operating procedures, maintenance practices and inspection programs in relation to the containment systems [31]. Lastly, under Directive 058, the AER is responsible for describing how the industry should manage oilfield wastes and identifying the oilfield waste management responsibilities of the licensee or approval holder. This promotes waste volume minimization and requires the recording, retention and submission of oilfield waster information [32].

Enforcement: Since all of the players within the industry must report, in regular intervals to the AER, the enforcement of these directives is currently considered to be in line with best practices. In addition, the AER publishes an annual report which helps to detail the fact that they do in fact make "spot" inspections, as well as follow up inspections to any incident that is reported to them [33].

\subsection{Wellbore Integrity}

The AER has set out strict requirements for industry when drilling into the ground for hydrocarbons. These regulations are primarily focused on ensuring that the casing that are utilized are held to a high standard and integrity. In order to do this there are three primary directives that have been established (see Table 2). The first two of these directives (008 and 009) are set out to ensure that the casings that are implemented in the extraction and production process meet their specific requirements in relation to depth and integrity of the casing. The last directive (083) is the same one that was discussed in the previous groundwater section.

Characterization of Risk. The primary risk related to wellbore integrity is the barrier leakage that can occur. This leakage can happen in a variety ways: pipes and casing can corrode over time, the cement casings can be subject to chemical or mechanical degradation, the valves that control the well can fail or leak, and/or the maintenance related to the well can be faulty [34]. There are additional risks that are created once the drilling shifts from vertical to horizontal, which is a significant component to fracking. These issues include: once turned sideways, these pipes are subject to much stronger gravitational forces which can pose challenges to cementing the pipe on a centered path and can lead to sagging [34].

Optimization of Mitigation Strategies. Technological advancements and engineering best practices have allowed for a substantial mitigation of the risk over the years (Table 3). Additionally, as operators continue to monitor and test the integrity of wellbores and casing (by way of sampling and recording well data) the risk of there being any substantial issues decreases [35].

Regulation: As stated in the regulation section of this paper, the AER has already incorporated mitigation strategies in the industry by enacting the following directives: 
Table 3. Historical environmental impact from oil and gas wells. Source: Bachu and Valencia 2014.

\begin{tabular}{|c|c|c|}
\hline Year (s) & Well construction and completion norms & $\begin{array}{l}\text { Potential for } \\
\text { pollution }\end{array}$ \\
\hline $1830-1916$ & Cable tool drilling, no cement isolation, wells vented & High \\
\hline 1916-1970 & Cement isolation steadily improving & Moderate \\
\hline 1930 s & $\begin{array}{c}\text { Rotary drilling replaces cable tool, pressure control } \\
\text { systems developed }\end{array}$ & Moderate \\
\hline 1952 & Hydraulic fracturing becomes commercial & $\begin{array}{l}\text { Lower from } \\
\text { frac aspects }\end{array}$ \\
\hline 1960 & Gas-tight couplings and joint makeup improvements & Moderate \\
\hline 1970 & Introduction of horizontal wells, cement improvements & Lower \\
\hline 1988 & $\begin{array}{l}\text { Multifrac, horizontal wells, pad drilling reduces } \\
\text { environmental land footprint up to } 90 \%\end{array}$ & Lower \\
\hline 2005 & $\begin{array}{l}\text { Well integrity assessments, premium couplings, } \\
\text { additional barriers, and cementing full strings }\end{array}$ & Lower after 2008-2010 \\
\hline 2008 & $\begin{array}{l}\text { Real-time well integrity needs being studied to achieve } \\
\text { early warning and problem avoidance }\end{array}$ & Lowest yet \\
\hline
\end{tabular}

- Directive 008: Surface Casing Depth Requirements.

- Directive 009: Casing Cementing Minimum Requirements.

- Directive 083: Hydraulic Fracturing-Subsurface Integrity.

These directives offer regulation that help to lead to best practices in the industry. They do this by giving guidelines for casing specifications in addition to regular reporting requirements.

Enforcement: By requiring operators to actively comply with the above regulations the opportunity for enforcement dramatically increases. In addition to these regulations, the AER actively ensures that operators are acting in accordance to these regulations by performing site inspections.

\subsection{Air Quality}

To address the air quality regulations that are required during this process, the Alberta government has established the Alberta Ambient Air Quality Objectives and Guidelines. Under these guidelines the government is able to establish acceptable levels of different chemicals that can be released into the atmosphere over given periods of time [13].

Characterization of Risk: With emissions being one of the principal contributors to climate change concerns the risks most prevalent to air quality come in the form of methane release from shale gas operations. Methane is one of the most potent of the greenhouse gasses as it can have up to 21 times the warming effect over a 100 year period compared to carbon dioxide [8]. Throughout the life span of a well these emissions can escape into the atmosphere during testing, completion and production (leaks).

Optimization of Mitigation Strategies. Since this primary risk is related to op- 
erational best practices, the AER partners with industry to help to reduce the likelihood and overall volume of these emissions over the well's lifespan. Industry players have introduced innovations related to improved metering and pressure controls that have reduced natural gas emissions significantly [28].

Regulation: The Alberta Environmental Protection and Enhancement Act has already laid out maximum emissions standards for a variety of gases over certain time intervals. Operators are required to report in regular intervals and are required to operate under the threshold of these guidelines [36].

Enforcement. By forcing operators to actively comply to the above regulations then the opportunity for enforcement dramatically increases. In addition to these regulations, the AER actively ensures that operators are acting in accordance to these regulations by performing site inspections.

\subsection{Noise and Light}

Since shale gas operations can occur in areas where citizens could reside nearby, the Alberta government, through the AER, has established two main directives (see Table 2) to help regulate the noise and light that is generated from these activities [18]. These directives address the impact of noise and light as part of energy development applications and specifically with noise levels of any operating energy project.

Characterization of Risk. This risk is mainly focused on upholding a reasonable quality of living for citizens who may reside close to where these operations take place [18]. Noise and light associated with shale gas operations are limited to the drilling and completion of the wells, and the operating of any ancillary metering or compression facilities. Given that these types of activities are done in large scale and are considered industrial, ensuring that they allow for residents to continue to live in their dwellings in a peaceful and harmonious fashion is the key objective.

Optimization of Mitigation Strategies. The best mitigation strategies that the AER has elected to pursue is to work closely with the communities and municipalities that are affected by these operations [18]. Industry has responded with innovation such as direct lighting and noise attenuating structures to house compressors.

Regulation: The AER has already set out two directives that help to regulate these activities to ensure the least amount of disruption to the communities. These directives are:

- Directive 056: Energy Development Applications and Schedules

- Directive 038: Noise Control

Through these regulations the AER can ensure that the drilling, completion and operation of shale gas wells do not unreasonably impact the local community.

Enforcement. The two principal directives are monitored by the AER and operators must first apply to drill before commencing development which establishes approved lighting and noise practices. 


\subsection{Induced Seismicity}

This refers to the seismic events (earthquakes) that may be triggered by the fracking operations that are being carried out by the industry. Currently, there are no specific regulations pertaining to this factor. However, the AER is in charge of monitoring these events through the Regional Alberta Observatory for Earthquakes Studies Network. Research into induced seismicity from oil field operations has found that fracking has created predominantly micro-earthquakes (too small to be felt) but there has been evidence of larger events where damage has occurred [37].

Characterization of Risk: One of the more controversial risks of shale gas production comes in the form of induced seismicity. The main causes of the seismic activities come from the removal of fluids and gases from sub-surface rock formations thus reducing pressure and increasing the risk of subsidence, the injection of fluids (fracking fluid) that increase formation pressures and results in creating microscopic fractures in the rock and the drilling and completion of wells proximal to existing fault lines.

Optimization of Mitigation Strategies: Since two of the risks are related to activities that can be quantified and monitored (injection and removal) the AER can continue to monitor and record these activities to see their impact. Additionally, the regulator can help to ensure that operators are not drilling into fault lines and control that through the application process which operators are required to fill out before starring activity. Collaboration is required with industry players so that technical evidence supporting the existence of large regional fracture systems is known to operators.

Regulation: There is currently no regulation in place specifically designed to control the generation of seismic activity. However, this is something that the AER continues to collect data on and monitor closely so that they will be able to create regulation if necessary. As of now the activities that could lead to induced seismicity are controlled by the directives mentioned earlier in this paper.

Enforcement: Due to the lack of specific regulation, there is no specific enforcement. There are strict reporting requirements that the AER requires, which are to be submitted by all operators so that the regulator can collect and monitor the data and activity to determine if existing regulations should be applied and enforced.

\section{Conclusions}

Environmental risks associated with shale gas production are well recognized. Water is required in the fracking process and local groundwater needs to be protected and the manner in which the water is used requires prudent management. Alberta's industry players have introduced innovative mitigation strategies to limit water use and the provincial government has established regulations and enforcement to encourage industry risk management in this area. As with water management and groundwater protection, the risks associated with wellbore in- 
tegrity have been mitigated using innovation in technology and engineering practices. Concerns exist around leakage of wellbore fluids through corroded casing, corroded valves or faulty cement bonds but historical regulation in $\mathrm{Al}$ berta around casing and cement testing and monitoring has led to best practices in industry that address these concerns.

Natural gas is predominantly composed of methane. Its potency as a greenhouse gas in terms of its contribution to globing warming means that emissions during shale gas testing, completion and production are risks that face the $\mathrm{Al}$ berta industry. Air quality regulation exists to establish maximum emission standards with industry operators required to report their levels from operations. Innovation in metering and pressure controls have helped mitigate emission risk.

Although most oil and gas operations occur away from residential development instances can exist when noise and light from shale gas development activities do impact residential dwellings. These activities are limited to the drilling and completion of the gas wells so regulations in Alberta require development applications to address how noise and light will be mitigated and the actual operation must adhere to noise control requirements. Once again, industry has employed innovative technologies to attenuate noise and reduce light pollution.

One area of exposure which may require more stringent regulation is induced seismicity resulting from shale gas development, however it is not yet clearly defined how this will happen. The reason for the lack of clarity around the induced seismic activity is that it is difficult to attribute to a specific operator or well. Currently, the AER is only a collector of the data related to seismic events and they have not indicated that there will be any regulation associated with this issue that might restrict shale gas production. Alberta's regulator monitors and records the injection and withdrawal of fluids that could contribute to this issue but co-operation from industry is required to mitigate seismic risk by recognizing the threat posed by drilling close to known fault systems that might be conducive to increased seismic activity.

From the analysis that has been conducted, there should not be any major impacts on current or future shale gas production due to environmental policy regulations within the province of Alberta. This conclusion has been reached by analyzing the current regulations that are currently in place within the province using the CO/RE model as well as the current direction that the AER is taking with their policy making. As stated in the above analysis, much of the regulation that the AER is responsible for has covered off the main issues regarding air quality controls, best practices with regards to well integrity, water related matters and that of the general public. Furthermore, Alberta's environmental regulation has influenced shale gas producers to pursue innovation in technology and engineering practice in order to meet the established regulatory requirements, and more importantly has established a collaborative approach to mitigating environmental risk. 


\section{References}

[1] McMahon, T. (2013) Welcome to the Golden Age of Shale Gas. MacLeans. http://www.macleans.ca/economy/business/the-golden-age-of-gas/

[2] Davenport, C. (2015) Nations Approve Landmark Climate Accord in Paris. The New York Times.

http://www.nytimes.com/2015/12/13/world/europe/climate-change-accord-paris.ht $\underline{\mathrm{ml} ? \mathrm{r}=0}$

[3] Jenner, S. and Lamadrid, A.J. (2013) Shale Gas vs. Coal: Policy Implications from Environmental Impact Comparisons of Shale Gas, Conventional Gas, and Coal on Air, Water, and Land in the United States. Energy Policy, 53, 442-453.

[4] Goldthau, A. and Sovacool, B.K. (2016) Energy Technology, Politics, and Interpretative Frames: Shale Gas Fracking in Eastern Europe. Global Environmental Politics, 16, 50-69.

[5] Houle, D., Lachapelle, E. and Purdon, M. (2015) Comparative Politics of Sub-Federal Cap-and-Trade: Implementing the Western Climate Initiative. Global Environmental Politics, 15, 49-73.

[6] Harrison, K. (2007) The Road Not Taken: Climate Change Policy in Canada and the United States. Global Environmental Politics, 7, 92-117.

[7] Howlett, M. (2014) Why Are Policy Innovations Rare and So Often Negative? Blame Avoidance and Problem Denial in Climate Change Policy-Making. Global Environmental Change, 29, 395-403.

[8] Konschnik, K.E. and Boling, M.K. (2014) Shale Gas Development: A Smart Regulation Framework. Environmental Science and Technology, 48, 8404-8416.

[9] Newell, R.G. and Raimi, D. (2014) Implications of Shale Gas Development for Climate Change. Environmental Science and Technology, 48, 8360-8368.

[10] Wihbey, J. (2015) Pros and Cons of Fracking: 5 Key Issues. Yale Climate Connection. http://www.yaleclimateconnections.org/2015/05/pros-and-cons-of-fracking-5-key-i $\underline{\text { ssues/ }}$

[11] Rivard, C., Lavoie, D., Lefebvre, R., Séjourné, S., Lamontagne, C. and Duchesne, M. (2014) An Overview of Canadian Shale Gas Production and Environmental Concerns. International Journal of Coal Geology, 126, 64-76.

[12] McGlade, C., Speirs, J. and Sorrell, S. (2013) Unconventional Gas-A Review of Regional and Global Resource Estimates. Energy, 55, 571-584.

[13] Natural Resource Canada (2016a) Regulation of Shale and Tight Resources. Natural Resources Canada.

[14] Beklumb, P., Chong, J. and Williams, T.G. (2015) Shale Gas in Canada: Environmental Risks and Regulation (Vols. 2015-18-E). Economics, Resources and International Affairs Division Parliamentary Information and Research Service, Ottawa.

[15] NEB (2016) Energy Market Assessment, Short-Term Canadian Natural Gas Deliverability, 2016-2018. National Energy Board.

[16] Alberta Energy (2016) Shale Gas. http://www.energy.alberta.ca/NaturalGas/944.asp

[17] Alberta Energy Regulator (2014) Alberta's Energy Reserves 2013 and Supply/Demand Outlook 2014-2023. Alberta Energy Regulator.

[18] Natural Resources Canada (2016) Alberta's Shale and Tight Resources. Natural Resources Canada.

[19] Environment and Climate Change Canada (2016) Achieving a Sustainable Future: A Federal Sustainable Development Strategy for Canada 2016-2019. Environment and 
Climate Change Canada.

[20] North, D., Warner, P., Stern, C., Webler, T. and Field, P. (2014) Public and Stakeholder Participation for Managing and Reducing the Risks of Shale Gas Development. Environmental Science and Technology, 48, 8388-8396. https://doi.org/10.1021/es405170k

[21] Gamper-Rabindran, S. (2014) Information Collection, Access, and Dissemination to Support Evidence-Based Shale Gas Policies. Energy Technology, 2, 977-987. https://doi.org/10.1002/ente.201402114

[22] Abrahams, L.S., Griffin, W.M. and Matthews, H.S. (2015) Assessment of Policies to Reduce Core Forest Fragmentation from Marcellus Shale Development in Pennsylvania. Ecological Indicators, 52, 153-160.

[23] Garvie, K.H. and Shaw, K. (2016) Shale Gas Development and Community Response: Perspectives from Treaty 8 Territory, British Columbia. Local Environment, 21, 1009-1028. https://doi.org/10.1080/13549839.2015.1063043

[24] Alberta Environment and Parks (2016) Water for Life. Alberta Environment and Parks.

[25] United States Environmental Protection Agency (2015) Assessment of the Potential Impacts of Hydraulic Fracturing for Oil and Gas on Drinking Water Resources. Office of Research and Development, Washington DC.

[26] Alberta Environment and Parks (2014) Our Water, Our Future a Conversation with Albertans Summary of Discussions. Alberta Environment and Parks, Edmonton.

[27] Arthur, J.D., Coughlin, B.J. and Bohm, B.K. (2010) Summary of Environmental Issues, Mitigation Strategies, and Regulatory Challenges Associated with Shale Gas Development in the United States and Applicability to Development and Operations in Canada. In Canadian Unconventional Resources and International Petroleum Conference. Society of Petroleum Engineers.

[28] Kiger, P.J. (2014) Green Fracking? 5 Technologies for Cleaner Shale Energy. National Geographic, 19.

[29] Alberta Energy Regulator (2013) Directive 083: Hydraulic Fracturing-Subsurface Integrity. Alberta Energy Regulator.

[30] Alberta Energy Regulator (2012) Directive 059: Well Drilling and Completion Data Filing Requirements. Alberta Energy Regulator.

[31] Alberta Energy Regulator (2001) Directive 055: Storage Requirements. Alberta Energy Regulator.

[32] Alberta Energy Regulator (2006) Directive 058: Oilfield Waste Management Requirements for the Upstream Petroleum Industry. Alberta Energy Regulator.

[33] Alberta Energy Regulator (2016) Annual Report 2015/16. Alberta Energy Regulator.

[34] Bachu, S. and Valencia, R.L. (2014) Well Integrity Challenges and Risk Mitigation Measures. The Bridge, 44, 28-33.

[35] Smith, L. (2013) Improving Shale Gas Safety with Well Integrity Management. Energy Digital. 22-29.

http://www.energydigital.com/utilities/2498/Improving-Shale-Gas-Safety-with-Well -Integrity-Management

[36] Alberta Environmental Protection and Enhancement Act (2013). http://www.qp.alberta.ca/documents/acts/e12.pdf

[37] McGarr, A., Bekins, B., Burkardt, N., Dewey, J., Earle, P., Ellsworth, W., Ge, S., et al. (2015) Coping with Earthquakes Induced by Fluid Injection. Science, 347, 830-831. https://doi.org/10.1126/science.aaa0494 
Submit or recommend next manuscript to SCIRP and we will provide best service for you:

Accepting pre-submission inquiries through Email, Facebook, LinkedIn, Twitter, etc. A wide selection of journals (inclusive of 9 subjects, more than 200 journals)

Providing 24-hour high-quality service

User-friendly online submission system

Fair and swift peer-review system

Efficient typesetting and proofreading procedure

Display of the result of downloads and visits, as well as the number of cited articles Maximum dissemination of your research work

Submit your manuscript at: http://papersubmission.scirp.org/

Or contact gep@scirp.org 